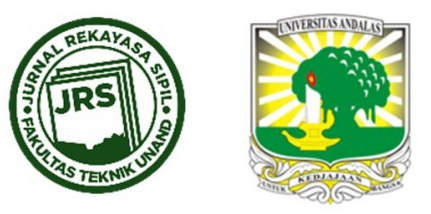

\title{
KAJIAN NILAI CALIFORNIA BEARING RATIO (CBR) PADA TANAH LEMPUNG LUNAK DENGAN VARIASI TEBAL STABILISASI MENGGUNAKAN ABU VULKANIK
}

\author{
AAZOKHI WARUWU ${ }^{1 *}$, OPTIMISMAN ZEGA ${ }^{1}$, DIAN RANO ${ }^{1}$, BABY MAUREENT ${ }^{1}$, \\ TESSALONIKA PANJAITAN ${ }^{1}$, SYUKURMAN HAREFA ${ }^{1}$ \\ ${ }^{1} J u r u s a n$ Teknik Sipil, Fakultas Teknik Sipil \& Perencanaan, Institut Teknologi Medan. Medan, Sumatera Utara, \\ Indonesia. \\ *Corresponding author: $ه$ azokhiw@gmail.com \\ Naskah diterima : 2 Juni 2021. Disetujui: 16 Juli 2021
}

\begin{abstract}
ABSTRAK
Tanah lempung lunak tidak dapat digunakan sebagai tanah dasar pada konstruksi jalan, jenis tanah ini memiliki nilai California Bearing Ratio(CBR) dan kuat tekan yang sangat rendah. Perbaikan tanah merupakan salah satu solusi yang baik apabila tanah ini terpaksa digunakan sebagai tanah dasar. Material stabilisasi tanah cukup beragam, namun perlu pertimbangan bahan yang tersedia dan melimpah di sekitar pekerjaan perbaikan tanah dilakukan. Kajian sederhana perlu dikembangkan melalui model perbaikan dengan skala kecil dalam bak uji. Hal ini bertujuan untuk mengetahui tebal lapisan tanah stabilisasi yang efektif dalam meningkatkan nilai CBR tanah. Penelitian ini menggunakan media tanah lempung lunak dan abu vulkanik sebagai bahan stabilisasi. Penambahan abu vulkanik ditentukan berdasarkan hasil terbaik dari uji kuat tekan bebas. Uji model dilakukan dalam bak uji berukuran $90 \mathrm{~cm} \times 120 \mathrm{~cm}$ x $90 \mathrm{~cm}$. Tanah lunak dipadatkan setiap $10 \mathrm{~cm}$ sampai 50 $\mathrm{cm}$. Tanah stabilisasi dipadatkan dengan tebal yang bervariasi dari $0-20 \mathrm{~cm}$. Selain tanah stabilisasi, uji CBR juga dilakukan pada lapisan pasir. Hasil penelitian menunjukkan bahwa penambahan 9\% abu vulkanik dari berat tanah kering dapat mengubah sifat tanah lunak menjadi lempung sangat kaku. Tebal tanah stabilisasi di atas $16 \mathrm{~cm}$ memperlihatkan perbaikan karakteristik tanah menjadi tanah sedang dengan nilai CBR mendekati $5 \%$. Nilai CBR tanah stabilisasi abu vulkanik didapatkan lebih tinggi 1,8 kali CBR lapisan pasir. Berdasarkan hasil penelitian, abu vulkanik didapatkan cukup efektif meningkatkan nilai CBR tanah, peningkatan yang didapatkan untuk tebal tanah stabilisasi $16-20 \mathrm{~cm}$ adalah 34-55 kali nilai CBR tanah lempung lunak (tanah asli).
\end{abstract}

Kata kunci : Tanah lempung lunak; Kuat tekan; CBR; Tebal tanah stabilisasi

\section{PENDAHULUAN}

Tanah lunak merupakan jenis tanah kohesif yang sebagian besar terdiri dari butiran dengan ukuran sangat kecil, baik tanah lempung maupun tanah lanau. Lempung terdiri dari butiran yang sangat kecil dan memiliki sifat kohesi dan plastisitas (Wesley, 2017). Tanah lempung termasuk sebagai tanah kohesif yang mempunyai kembang susut tinggi dan daya dukung yang rendah (Zaro et al., 2014). Sifat-sifat tanah lunak terdiri dari konsistensi lunak ke sangat DOI : https://doi.org/10.25077/jrs.17.2.116-130.2021 
lunak, kadar air tinggi, kuat geser rendah, pemampatan tinggi, dan daya dukung rendah (Alawiah \& Yakin, 2016; Darmawandi et al., 2020). Akibat daya dukung rendah, tanah lunak sangat berpotensi mengalami penurunan, sehingga dapat menimbulkan permasalahan pada kestabilan konstruksi.

Tanah lempung lunak mengandung mineral-mineral lempung dan kadar air yang tinggi, yang dapat menyebabkan kuat geser undrained $\left(c_{u}\right)$ rendah. Tanah lempung dapat dikelompokkan sebagai tanah lunak, apabila mempunyai kuat geser undrained lebih kecil dari $25 \mathrm{kPa}$, nilai ini dapat ditentukan dari uji kuat tekan bebas (Darmawandi et al., 2020). Nilai kuat tekan $\left(q_{u}\right)$ yang lebih kecil dari $50 \mathrm{kPa}$ atau nilai $c_{u}$ lebih kecil dari $25 \mathrm{kPa}$ digolongkan sebagai tanah lempung lunak ke sangat lunak (Hardiyatmo, 2002). Tanah lempung lunak mengalami permasalahan jika digunakan sebagai tanah dasar (subgrade) konstruksi jalan, jenis tanah ini perlu perbaikan sebelum dijadikan sebagai tanah dasar (Satria et al., 2020).

Tanah dasar merupakan tanah pondasi yang mendukung beban secara langsung berupa berat lapisan perkerasan dan beban kendaraan yang melintas di atas permukaan jalan. Karakteristik tanah asli dari tanah dasar sangat menentukan kekuatan konstruksi jalan dalam menjamin kestabilan dan keamanan berkendaraan. Lapisan perkerasan dan permukaan jalan sebagai pelindung untuk tanah dasar berfungsi untuk mendistribusikan beban roda kendaraan ke tanah dasar. Tanpa dukungan yang cukup dari tanah dasar, perkerasan akan mudah mengalami kerusakan. Dukungan tanah dasar pada perkerasan ini dipengaruhi oleh karakteristiknya. Tanah dasar yang dipilih seharusnya memiliki karakteristik yang memadai dan memenuhi syarat dan ketentuan. Namun masih banyak tanah dasar yang mempunyai karakteristik kurang baik sebagai tanah dasar (subgrade).

Lapisan tanah dasar sebagai pondasi jalan sangat penting pada konstruksi perkerasan, karena memiliki fungsi untuk mendukung lapisan pondasi bawah, lapisan pondasi atas, lapisan permukaan, dan beban kendaraan. Tanah dasar merupakan bagian terakhir yang menerima distribusi beban dari lapisan-lapisan di atasnya. Tanah dasar berpengaruh pada pembiayaan pembangunan jalan raya, karena semakin rendah daya dukung tanah dasar maka lapisan perkerasan jalan semakin tebal. Selain biaya konstruksi, sifat-sifat dan daya dukung tanah dasar ikut mempengaruhi kekuatan dan keawetan konstruksi perkerasan jalan (Sukirman, 1999). Integritas dari struktur lapisan perkerasan bergantung pada stabilisasi tanah dasar, karena tanah dasar merupakan bagian dari timbunan dimana pondasi bawah, pondasi atas, dan permukaan perkerasan berada.

Karakteristik yang perlu diketahui pada tanah dasar jalan adalah nilai CBR tanah. Permasalahan yang sering dijumpai pada tanah dasar jalan adalah masalah daya dukung tanah rendah yang ditandai dengan rendahnya nilai California Bearing Ratio (CBR). Batasan nilai CBR untuk tanah dasar minimal $6 \%$, agar lapisan perkerasan tidak mudah mengalami retak dan runtuh akibat terjadinya penurunan badan jalan (Soedarsono, 1985). Menurut Bowles (1992), tanah dengan nilai CBR $<3 \%$ diklasifikasikan sebagai tanah dengan CBR rendah, 3-7\% sebagai tanah dengan CBR rendah sampai sedang, 7-20\% sebagai tanah dengan CBR sedang, dan $>20 \%$ sebagai tanah dengan CBR baik.

Nilai CBR tanah dasar menjadi acuan pada perencanaan perkerasan jalan raya, oleh karena itu nilai CBR tanah dasar seharusnya memenuhi persyaratan nilai tertentu, selain persyaratan lainnya. Berdasarkan nilai CBR, tanah dasar untuk jalan dikelompokkan dalam beberapa klasifikasi seperti yang diuraikan dalam Tabel 1 (Soedarsono, 1985). 
Konstruksi jalan diharapkan dapat dibangun di atas tanah dasar yang tergolong dalam klasifikasi baik. Oleh karena itu, tanah dasar yang tergolong jelek memerlukan upaya perbaikan agar memenuhi syarat yang diperlukan. Usaha perbaikan tanah dasar yang jelek dapat dilakukan melalui proses stabilisasi tanah. Salah satu proses perbaikan sifat-sifat tanah adalah menambahkan material tertentu pada tanah, sehingga dapat menaikkan kekuatan tanah dan memperbaiki kekuatan geser (Hardiyatmo, 2002). Tanah lempung yang dipengaruhi oleh fruktuasi kadar air mengakibatkan perubahan volume besar, dan jika kadar air mendekati kadar air optimum dari pemadatan standar, maka terjadi perubahan kekuatan dan kekakuan yang signifikan (Hardiyatmo, 2015). Beberapa material tambahan yang digunakan sebagai bahan stabilisasi tanah di antaranya fly ash, semen, kapur, aspal emulsi, dan abu vulkanik.

Tabel 1. Klasifikasi Tanah Dasar untuk Jalan (Soedarsono, 1985)

\begin{tabular}{llll}
\hline No. & Klasifikasi & Jenis jalan & CBR (\%) \\
\hline 1 & Sangat baik & a. Sirtu & $25-60$ \\
& & b. Kerikil atau pasir & $20-60$ \\
\hline 2 & Baik & a. Pasir kasar & $10-30$ \\
& & b. Pasir halus & $6-26$ \\
\hline 3 & Sedang & Lanau dan lempung & $4-15$ \\
\hline 4 & Jelek & Lempung organik & $3-8$ \\
\hline 5 & Sangat jelek & Humus / tanah organik & $<3$ \\
\hline
\end{tabular}

Perbaikan tanah dapat dilakukan dengan material stabilisasi dari semen dan kapur, penambahan 3\% semen dan 4\% kapur dapat memperbesar kuat tekan bebas tanah jenis CLML (Tornando et al., 2020). Stabilisasi tanah bertujuan untuk meningkatkan kapasitas daya dukung tanah dasar jalan. Menurut Darwis (2017), beberapa jenis perbaikan tanah yang telah dikembangkan dengan menggunakan bahan abu sebagai bahan campuran, dapat berasal dari abu terbang, dan abu sekam. Jenis abu lainnya yang pernah diteliti adalah sebagai bahan tambah pada tanah lempung adalah abu batu dan cornice adhesive (Waruwu, 2012; Waruwu, 2013).

Material yang digunakan untuk perbaikan tanah sangat beragam, hal ini disesuaikan dengan ketersediaan material di daerah yang membutuhkan perbaikan tanah. Jenis abu lainnya yang perlu pengembangan secara berkelanjutan adalah abu vulkanik, karena mengingat semakin melimpahnya limbah dari bahan material vulkanik jatuhan yang disemburkan ke udara saat terjadi letusan gunung berapi. Penambahan 9\% abu vulkanik pada tanah lempung dapat meningkatkan nilai kuat tekan dan CBR tanah (Triputro \& Rahayu, 2016). Abu vulkanik dapat memperbaiki sifat-sifat tanah karena memiliki kandungan Silika ( $\mathrm{Si}$ ) yang cukup tinggi sekitar 70,6\%, selain kandungan kimia lainnya Alumina (Al) 1,8-15,9\%, seperti Zat besi (Fe) 1,4-9,3\%, Magnesium (Mg) 0,1-2,4\%, dan Kalsium (Ca) 0,7\% (Triputro \& Rahayu, 2016). Nilai kuat tekan tanah lempung tanpa perbaikan hanya $76 \mathrm{kPa}$ meningkat menjadi $120 \mathrm{kPa}$ dengan penambahan $9 \%$ abu vulkanik. Hal yang sama didapatkan pada peningkatan nilai CBR tanah lempung tanpa abu vulkanik sebesar $1,3156 \%$ menjadi $1,4027 \%$ setelah penambahan $9 \%$ abu vulkanik. Pencampuran abu vulkanik dan kapur sebagai bahan stabilisasi tanah lempung ekspansif dapat meningkatkan berat isi tanah, nilai geser tanah, dan mengurangi kadar air dan tingkat pengembangan tanah lempung (Latif et al., 2017). Campuran 3\% abu vulkanik dan 10\% abu sekam dapat meningkatkan nilai CBR tanah lempung (Rinaldi et al., 2020). Hasil-hasil penelitian sebelum ini menjadi dasar pertimbangan dipilihnya bahan abu vulkanik sebagai bahan stabilisasi, selain karena bahan ini merupakan limbah yang kurang mendapat perhatian masyarakat. 
Apabila lapisan perkerasan kaku semakin tebal di atas tanah dasar yang lunak dengan daya dukung rendah, maka luas bidang kontak dari penyebaran tekanan akan semakin lebar, sehingga tekanan dari beban roda kendaraan akan semakin mengecil (Hardiyatmo, 2016). Namun, pada penelitian ini yang dipertebal adalah bukan lapisan perkerasannya melainkan tebal lapisan tanah stabilisasinya, dengan harapan tebal lapisan perkerasan semakin berkurang, tetapi luas bidang kontak dari penyebaran tekanan tetap semakin melebar.

Penelitian sebelumnya umumnya menggunakan uji CBR laboratorium dalam mendapatkan karakteristik tanah stabilisasi dengan abu vulkanik, namun pada penelitian ini kebaharuan yang dilakukan adalah kajian penerapan stabilisasi pada model skala kecil melalui bak uji pada tanah lempung lunak dengan meninjau variasi tebal tanah stabilisasi abu vulkanik. Penambahan abu vulkanik dipilih berdasarkan kinerja yang baik pada peningkatan nilai kuat tekan.

Peningkatan nilai CBR tanah stabilisasi dibandingkan dengan nilai CBR lapisan pasir yang memiliki ukuran tebal yang sama dengan tanah stabilisasi. Kajian ini dapat menjadi dasar pertimbangan pada pelaksanaan tebal tanah stabilisasi di lapangan. Penelitian ini bertujuan untuk mengetahui penambahan abu vulkanik yang efektif ditinjau dari nilai kuat tekan bebas dan untuk mengetahui efektivitas tebal lapisan tanah stabilisasi abu vulkanik dalam memperbaiki karakteristik tanah ditinjau dari peningkatan nilai CBR.

\section{METODA PENELITIAN}

Bahan yang digunakan pada penelitian ini terdiri dari tanah lempung lunak (soft clay) sebagai media penelitian, dan abu vulkanik sebagai bahan campuran stabilisasi tanah lunak. Tanah lunak yang diuji berasal dari daerah Desa Pematang, Biara Kecamatan Pantai Labu, Kabupaten Deli Serdang. Tanah lempung lunak dikeringkan di bawah sinar matahari, lalu ditumbuk dan dihaluskan untuk kemudian diayak pada saringan No. 40. Abu vulkanik sebagai sebagai bahan stabilisasi diambil dari Gunung Sinabung, Desa Singgarang-garang Kabanjahe, Sumatera Utara. Abu vulkanik yang sudah dikeringkan di bawah panas sinar matahari, lalu diayak pada saringan No. 40.

Penelitian ini diawali dengan pengujian sifat fisik dan mekanik tanah lunak dan pengujian tanah stabilisasi dengan abu vulkanik. Beberapa pengujian awal pada tanah asli dan tanah stabilisasi di antaranya batas-batas Atterberg, analisa saringan, hydrometer, berat jenis, pemadatan standar, dan kuat tekan bebas. Selain tanah stabilisasi dengan abu vulkanik, juga dilakukan pengujian menggunakan pasir. Material pasir diuji dengan analisa saringan, berat jenis, berat volume, dan uji geser langsung.

Pengujian pemadatan standar dan kuat tekan bebas dilakukan pada campuran tanah dengan abu vulkanik variasi $3 \%, 6 \%, 9 \%$, dan $12 \%$ dari berat tanah kering. Hal ini diperlukan untuk menentukan persentase tambahan abu vulkanik yang menghasilkan kuat tekan tertinggi. Persentase penambahan terbaik digunakan sebagai campuran untuk tanah stabilisasi pada uji CBR dalam bak pengujian.

Pengujian selanjutnya dilakukan dengan uji CBR lapangan pada tanah stabilisasi yang dipadatkan dalam bak pengujian. Bak uji ini berfungsi sebagai tempat untuk pengujian pemodelan stabilisasi tanah lunak. Ukuran bak uji ini adalah lebar $90 \mathrm{~cm}$, tinggi $90 \mathrm{~cm}$, dan panjang $120 \mathrm{~cm}$. Dasar bak uji diisi dengan lapisan padat dari pasir dan batu agar lapisan tanah lempung lunak tidak mengalami penurunan, selanjutnya tanah lunak dimasukkan ke dalam bak uji setebal $10 \mathrm{~cm}$ dan dipadatkan dengan alat pemadat mendekati kepadatan tanah lempung di lokasi pengambilan sampel, hal yang sama dilakukan pada lapisan $10 \mathrm{~cm}$ 
berikutnya sampai dengan ketebalan $50 \mathrm{~cm}$. Skema uji dalam bak uji dapat dilihat pada Gambar 1. Setiap pemadatan lapisan tanah diuji dengan uji core cutter untuk memastikan kesesuaian kepadatan yang diperlukan. Lubang bekas core cutter ditutup dengan tanah dan dipadatkan kembali. Uji core cutter merupakan pengujian yang dilakukan untuk mengetahui berat isi $(\gamma)$ tanah lunak di dalam bak uji, supaya kepadatan tanah mendekati dengan kondisi di lapangan.

Tanah stabilisasi dengan tebal bervariasi merupakan campuran terbaik dengan tanah lempung lunak. Campuran terbaik dilihat dari hasil uji pemadatan standar dan kuat tekan bebas. Tanah yang telah dikeringkan lalu ditumbuk dan disaring pada saringan No. 40, kemudian dicampurkan dengan abu vulkanik sesuai persentase terbaik. Tanah stabilisasi yang telah dicampur dan diperam selama 1 hari dimasukkan dan dipadatkan dalam lubang uji berukuran $30 \mathrm{~cm}$ x $30 \mathrm{~cm}$ (Gambar 2).

Kepadatan tanah stabilisasi mengikuti kepadatan maksimum dari pemadatan standar dengan penambahan air sebanyak kadar air optimum. Variasi tebal tanah stabilisasi di antaranya $0 \mathrm{~cm}, 4 \mathrm{~cm}, 8 \mathrm{~cm}, 12 \mathrm{~cm}, 16 \mathrm{~cm}$, dan $20 \mathrm{~cm}$. Kinerja tanah stabilisasi dibandingkan dengan kinerja lapisan pasir tanpa campuran tanah. Pasir dipadatkan dalam lubang uji dengan ukuran dan tebal lapisan yang sama dengan tanah stabilisasi abu vulkanik.

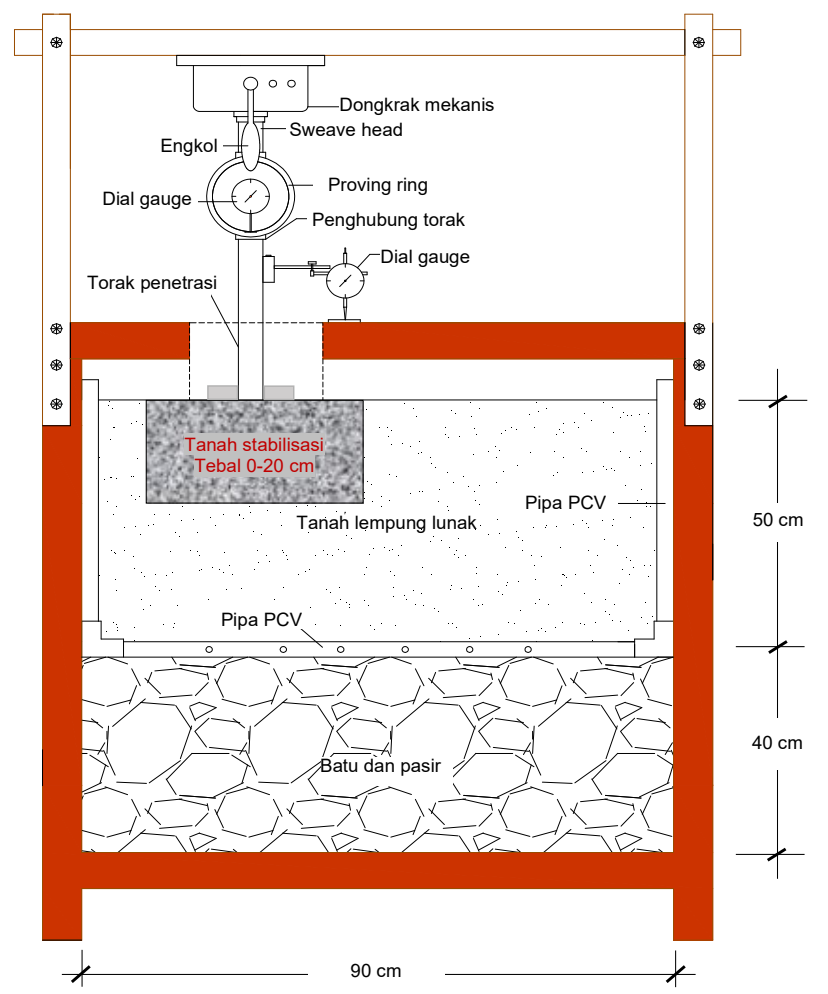

Gambar 1. Skema model uji dalam bak pengujian

Pengujian CBR lapangan dilakukan pada setiap titik tanah stabilisasi dan lapisan pasir yang telah siap diuji (Gambar 3). Hasil uji CBR lapangan digunakan untuk menentukan nilai CBR tanah stabilisasi pada masing-masing tebal lapisan tanah. Kinerja daripada tanah stabilisasi dilihat dari peningkatan nilai CBR pada setiap penambahan tebal lapisan tanah, kemudian dibandingkan dengan nilai CBR lapisan pasir tanpa campuran tanah. 


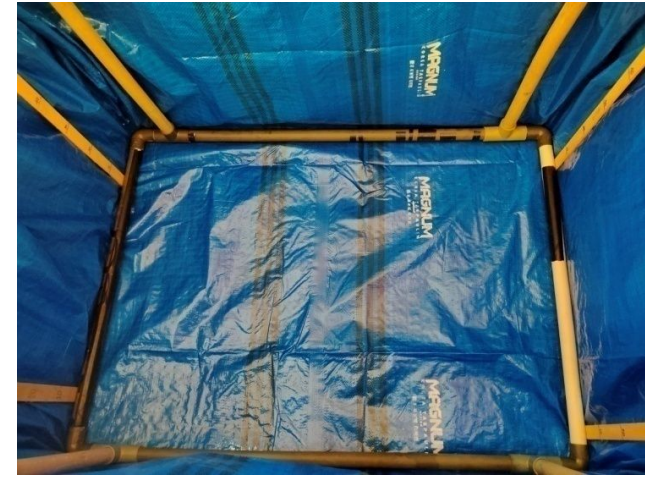

(a)

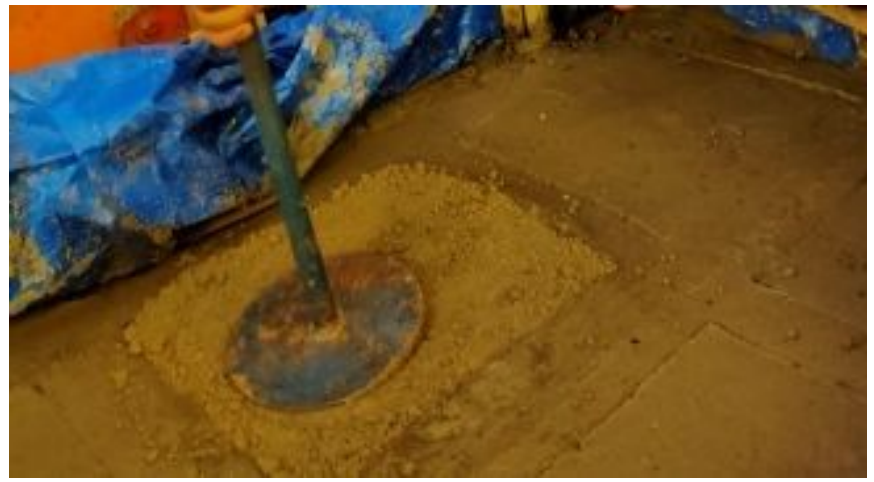

(b)

Gambar 2. Proses pengujian: (a) Persiapan bak uji; (b) Pemadatan tanah stabilisasi

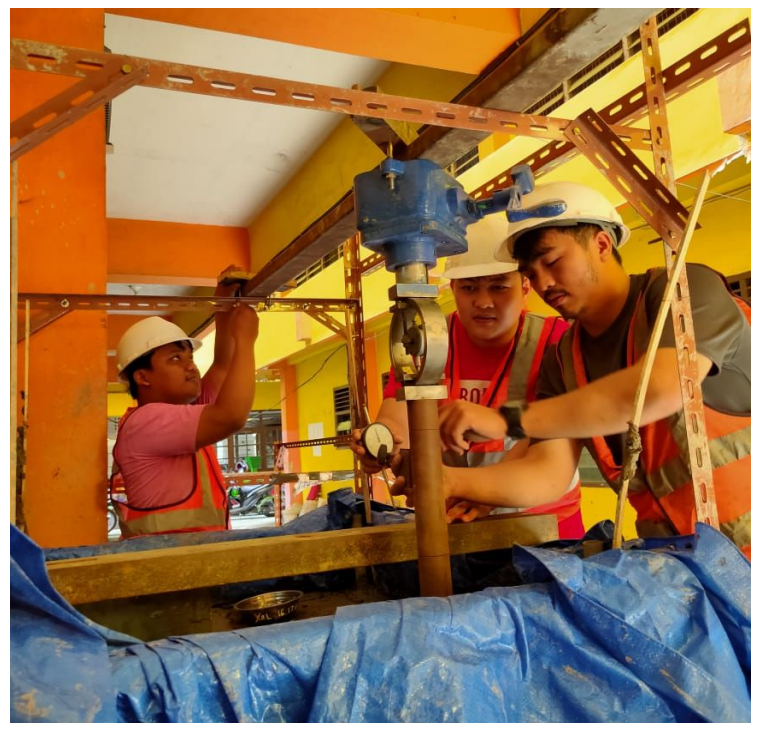

Gambar 3. Uji CBR dalam bak pengujian

\section{HASIL DAN PEMBAHASAN}

\subsection{Hasil Uji Sifat-sifat Tanah}

Tanah yang diuji terdiri dari 3 (tiga) jenis, di antaranya tanah lempung lunak tanpa stabilisasi, tanah lempung yang distabilisasi dengan abu vulkanik, dan pasir yang digunakan sebagai pembanding hasil uji CBR. Awal pengujian ditujukan pada tanah lempung yang diambil dari lapangan, pengujian ini diperuntukkan sebagai acuan untuk menentukan karakteristik tanah yang digunakan. Berdasarkan hasil analisa saringan didapatkan bahwa tanah ini memiliki jumlah lolos saringan No. 200 sebanyak 97,56. Nilai batas cair $(L L)$ dan indeks plastis (PI) berturut-turut $57,27 \%$ dan $21,20 \%$ (Tabel 2). Berdasarkan klasifikasi AASHTO, tanah ini termasuk dalam kelompok tanah berlempung dengan simbol A-7, karena jumlah lolos saringan No. $200(0,075 \mathrm{~mm})>35 \%, L L>41 \%$, dan $P I>11 \%$ (Hardiyatmo, 2002). Apabila tanah ini digunakan sebagai tanah dasar, maka termasuk tanah dasar buruk.

Nilai berat isi kering maksimum dari uji pemadatan standar dan nilai kuat tekan $\left(q_{u}\right)$ dari uji kuat tekan bebas pada tanah dengan campuran 0-12\% dapat dilihat pada Gambar 4. 
Berdasarkan nilai $q_{u}$ pada tanah tidak terganggu, maka tanah ini digolongkan sebagai tanah lunak karena memiliki nilai $q_{u}<0,5 \mathrm{~kg} / \mathrm{cm}^{2}$ atau $50 \mathrm{kPa}$ (Hardiyatmo, 2002). Dengan demikian, tanah yang diteliti ini merupakan tanah lempung lunak.

Berdasarkan hasil uji pemadatan standar dan uji kuat tekan bebas ditemukan bahwa campuran $9 \%$ abu vulkanik memperlihatkan nilai tertinggi baik nilai kuat tekan maupun nilai berat isi kering maksimum ( $\left.\gamma_{d \max }\right)$. Seperti ditunjukkan pada Tabel 2, nilai $q_{u}$ dan $\gamma_{d \max }$ untuk tanah dan $9 \%$ abu vulkanik masing-masing $2,99 \mathrm{~kg} / \mathrm{cm}^{2}$ atau $299 \mathrm{kPa}$ dan $1,39 \mathrm{~kg} / \mathrm{cm}^{3}$. Penambahan $9 \%$ abu vulkanik mengubah karakteristik tanah lunak lunak menjadi lempung sangat kaku karena memiliki nilai $q_{u}$ antara $200-400 \mathrm{kPa}$ (Hardiyatmo, 2002). Hal yang sama didapatkan dari hasil penelitian Triputro \& Rahayu (2016) pada tanah lempung, bahwa penambahan $9 \%$ kadar abu vulkanik dapat memberikan peningkatan nilai kuat tekan dan nilai CBR tanah yang signifikan. Atas dasar inilah, maka untuk pengujian CBR dalam bak uji, hanya menggunakan penambahan $9 \%$ abu vulkanik dan sebagai pembandingnya dilakukan pengujian CBR pada lapisan pasir dengan sifat-sifat seperti diuraikan dalam Tabel 2. Penambahan abu vulkanik pada tanah lempung lunak dapat memperbaiki sifatsifat fisik tanah, mengurangi indeks plastisitas, meningkatkan berat isi kering, dan mengurangi kadar air.

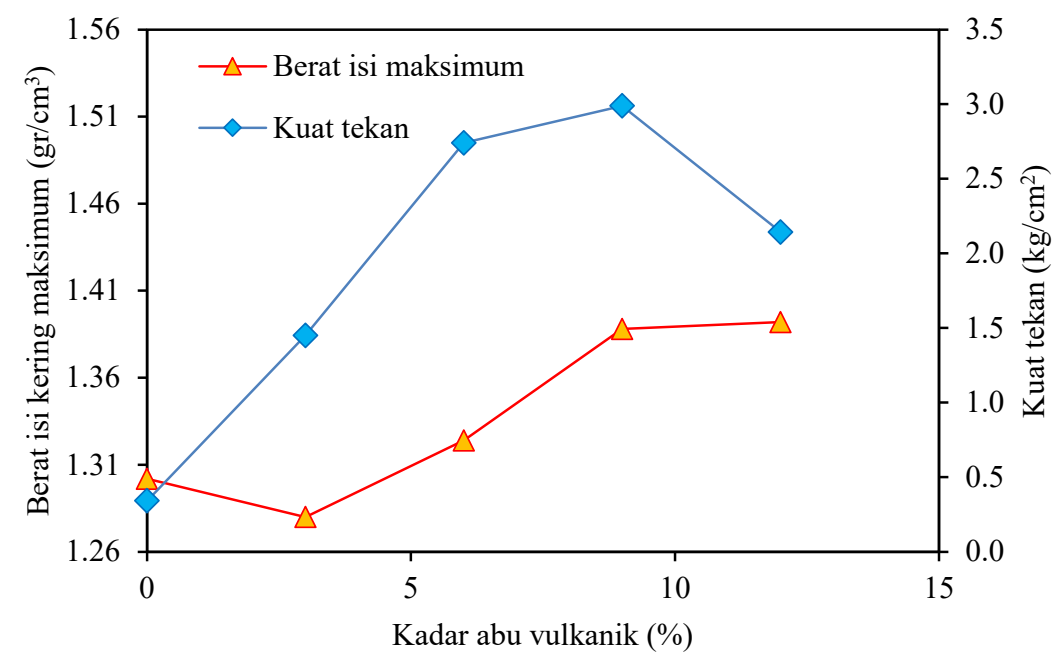

Gambar 4. Berat isi kering dan kuat tekan tanah stabilisasi

Tabel 2. Sifat-sifat tanah yang diteliti

\begin{tabular}{lllll}
\hline Sifat-sifat tanah & Satuan & $\begin{array}{l}\text { Tanah lempung } \\
\text { lunak }\end{array}$ & $\begin{array}{l}\text { Tanah stabilisasi } \\
\text { abu vulkanik }\end{array}$ & Pasir \\
\hline Kadar air asli & $\%$ & 73,70 & - & 12,77 \\
\hline $\begin{array}{l}\text { Berat isi basah } \\
\text { tanah asli }\end{array}$ & $\mathrm{gr} / \mathrm{cm}^{3}$ & 1,628 & - & 1,707 \\
\hline Batas cair $(L L)$ & $\%$ & 57,27 & 57,34 & - \\
\hline Batas plastis $(P L)$ & $\%$ & 36,07 & 36,43 & - \\
\hline $\begin{array}{l}\text { Indeks plastisitas } \\
(P I)\end{array}$ & $\%$ & 21,20 & 20,91 & 27,68 \\
\hline $\begin{array}{l}\text { Lolos analisa } \\
\text { saringan No. } 200\end{array}$ & $\%$ & 97,56 & 97,18 & - \\
\hline $\begin{array}{l}\text { Berat isi kering } \\
\text { maksimum }(\gamma d)\end{array}$ & $\mathrm{gr} / \mathrm{cm}^{3}$ & 1,30 & 1,39 & - \\
\hline $\begin{array}{l}\text { Kadar air optimum } \\
(w)\end{array}$ & $\%$ & 34,30 & 28,21 & \\
\hline
\end{tabular}




\begin{tabular}{lllll}
\hline Sifat-sifat tanah & Satuan & $\begin{array}{l}\text { Tanah lempung } \\
\text { lunak }\end{array}$ & $\begin{array}{l}\text { Tanah stabilisasi } \\
\text { abu vulkanik }\end{array}$ & Pasir \\
\hline Berat jenis $(G s)$ & - & 2,64 & 2,57 & 2,59 \\
\hline Kuat tekan $\left(q_{u}\right)$ & $\mathrm{kg} / \mathrm{cm}^{2}$ & 0,34 & 2,99 & - \\
\hline $\begin{array}{l}\text { Sudut geser dalam } \\
(\varphi)\end{array}$ & 0 & - & - & 36,29 \\
\hline
\end{tabular}

Hasil uji core cutter ditunjukkan pada Gambar 5. Pengambilan data kepadatan dilakukan setiap kedalaman $10 \mathrm{~cm}$ sebanyak 5 (lima) titik. Nilai berat isi basah rata-rata dan kadar air di setiap kedalaman ditunjukkan dalam Gambar 5. Berat isi basah rata-rata dari permukaan tanah sampai kedalaman $50 \mathrm{~cm}$ sebesar $1,61 \mathrm{gr} / \mathrm{cm}^{3}$ mendekati sama dengan berat isi basah tanah asli di lapangan $1,628 \mathrm{gr} / \mathrm{cm}^{3}$. Sedangkan kadar air tanah lempung lunak dalam bak uji didapatkan sebesar $73,80 \%$ mendekati kadar air tanah asli di lapangan sebesar $73,70 \%$ (Tabel 2).

\subsection{Hasil Uji CBR Tanah}

Hasil uji CBR tanah yang distabilisasi $9 \%$ abu vulkanik dalam bak uji dapat dilihat pada Gambar 6. Uji CBR dilakukan pada setiap titik tertentu yang dibedakan berdasarkan tebal lapisan tanah. Kepadatan tanah dengan 9\% abu vulkanik mengacu pada hasil pemadatan standar dengan berat volume maksimum $1,39 \mathrm{gr} / \mathrm{cm}^{3}$ dan kadar air optimum $28,21 \%$ (Tabel 2). Hasil uji CBR menunjukkan bahwa beban-beban yang diterapkan pada lapisan tanah stabilisasi terlihat meningkat secara linier di menit-menit awal, namun pada penetrasi tertentu mencapai beban maksimum dan kemudian landai bahkan semakin kecil, hal ini menunjukkan bahwa lapisan tanah pada awal-awal pembebanan mengalami penurunan elastis, sedangkan pada beban maksimum kemampuan tanah menjadi terlampaui.

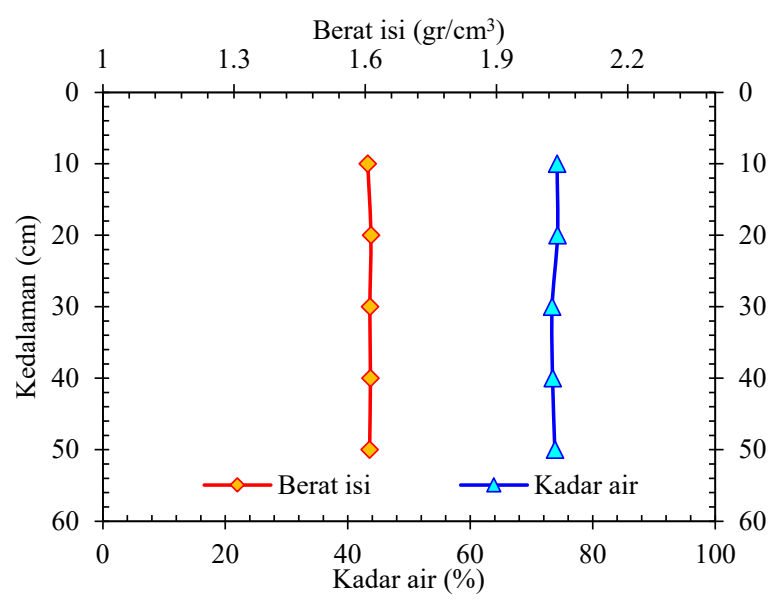

Gambar 5. Hasil uji core cutter tanah lempung lunak dalam bak uji

Pengaruh ketebalan tanah stabilisasi abu vulkanik berpengaruh pada hubungan penetrasi dengan beban pada hasil uji CBR. Hasil pembacaan beban dalam proving meningkat seiring dengan semakin tebalnya lapisan tanah stabilisasi. Hal ini menunjukkan bahwa kemampuan tanah yang distabilisasi dengan abu vulkanik dalam menerima beban semakin meningkat. Peningkatan yang signifikan terjadi pada ketebalan $16 \mathrm{~cm}$ ke atas. Hal yang sama terjadi pada penelitian (Moayed et al., 2012), yang meninjau pengaruh ketebalan tanah granuler ( $40 \mathrm{~mm}, 55 \mathrm{~mm}$, dan $70 \mathrm{~mm}$ ) di atas tanah kohesif, pada penetrasi yang sama didapatkan bahwa lapisan stabilisasi yang lebih tebal memperlihatkan tegangan yang lebih besar. 


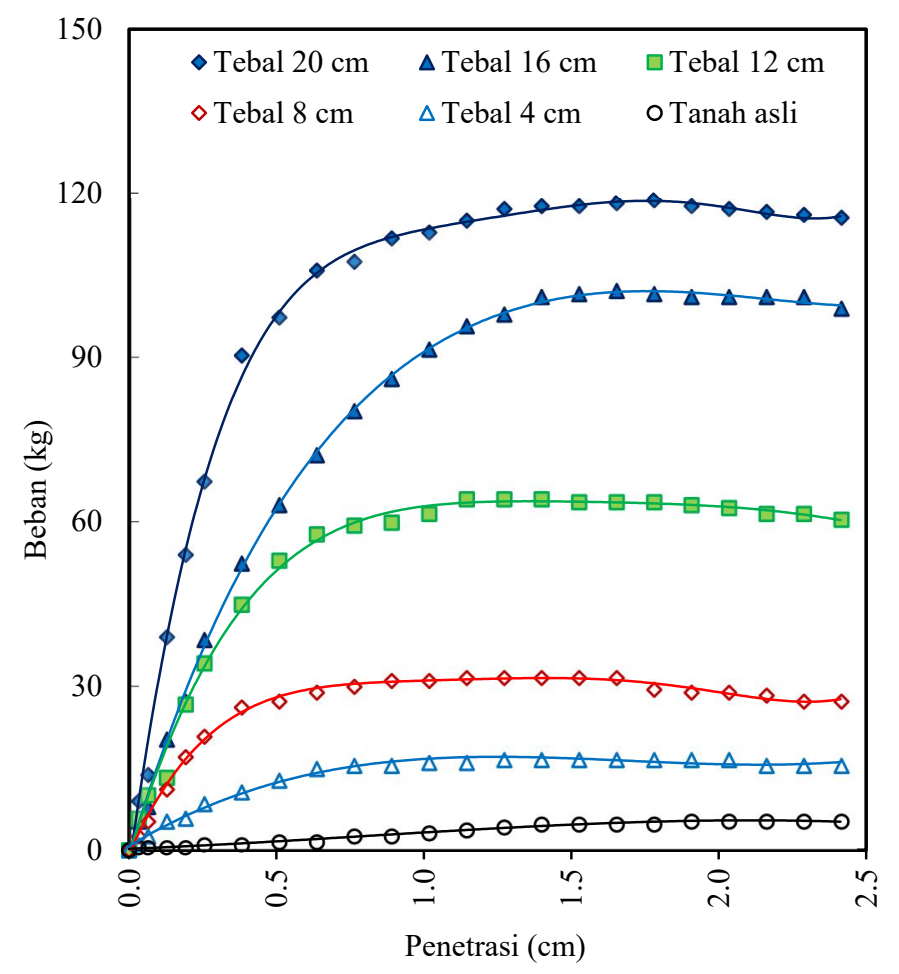

Gambar 6. Hasil uji CBR pada tanah dengan stabilisasi abu vulkanik

Hasil uji CBR pada lapisan tanah pasir dalam bak uji ditunjukkan pada Gambar 7. Hasil pengujian CBR tanah pasir menunjukkan bahwa hubungan linier antara beban dan penetrasi terlihat tidak berlangsung lama, hal ini disebabkan lapisan pasir mudah runtuh saat diberi beban. Keruntuhan pasir dibuktikan dengan puncak beban yang relatif rendah dibandingkan tanah lempung yang distabilisasi abu vulkanik.

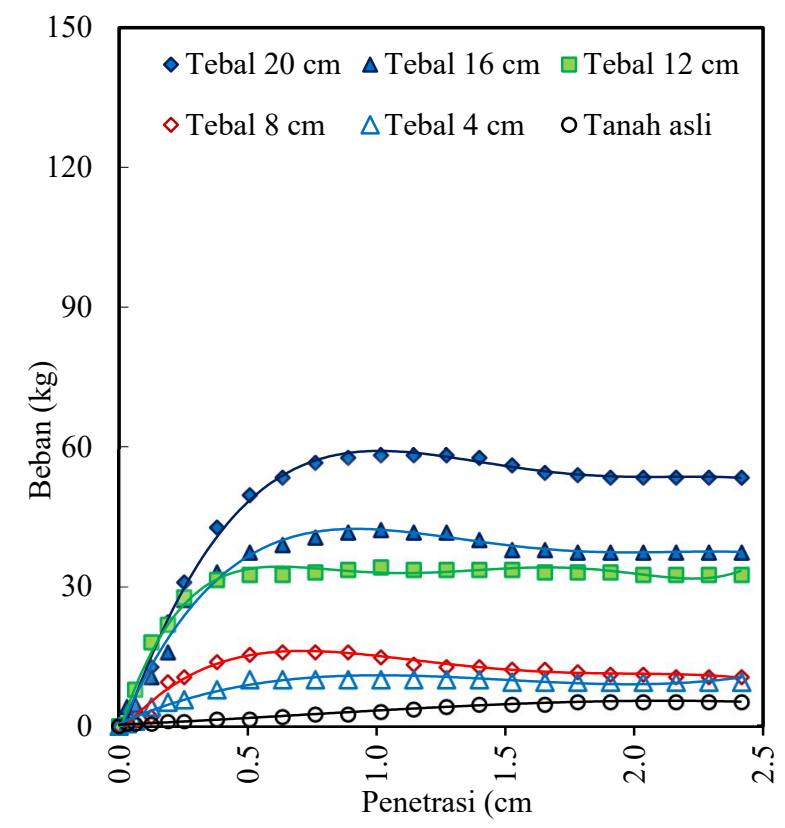

Gambar 7. Hasil uji CBR pada tanah dengan lapisan pasir lepas 


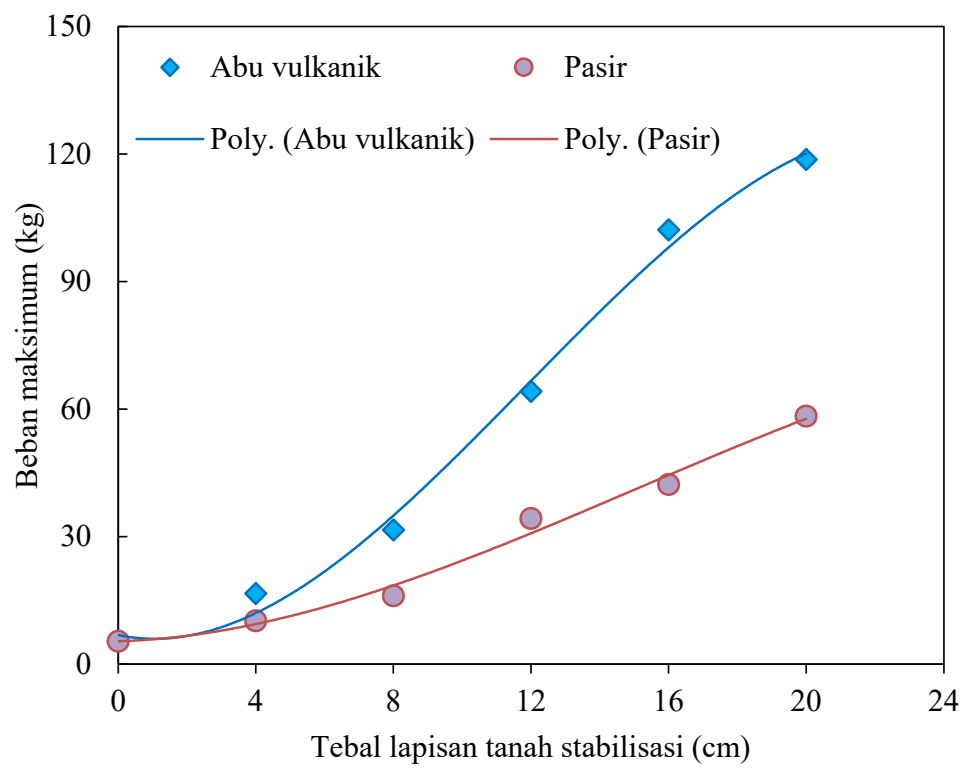

Gambar 8. Beban maksimum setiap tebal lapisan tanah stabilisasi

Perbandingan beban maksimum yang bekerja dalam lapisan tanah stabilisasi dan lapisan pasir dapat dilihat pada Gambar 8. Hubungan ini membuktikan bahwa daya dukung tanah stabilisasi $9 \%$ abu vulkanik jauh lebih tinggi daripada tanah pasir. Apabila beban maksimum keduanya dibandingkan, maka didapatkan tanah stabilisasi $9 \%$ abu vulkanik memiliki kemampuan sekitar 2 kali lipat beban maksimum pasir.

\subsection{Perbandingan Nilai CBR Tanah Stabilisasi dengan Pasir}

Hasil uji CBR pada tanah stabilisasi $9 \%$ abu vulkanik dan lapisan pasir dengan tebal $16 \mathrm{~cm}$ diperlihatkan pada Gambar 9. Nilai CBR ditentukan dari beban pada penetrasi $0,254 \mathrm{~cm}$ $(0,1$ ”) atau $0,508 \mathrm{~cm}(0,2$ "), biasanya diambil nilai yang menghasilkan CBR terbesar. Nilai CBR dihitung dari perbandingan beban dengan beban standar, untuk 0,1" sebesar $3000 \mathrm{lbs}$ $(1360,78 \mathrm{~kg}$ ) dan untuk 0,2" sebesar $4500 \mathrm{lbs}(2041,16 \mathrm{~kg})$. Persentase dari keduanya merupakan nilai $\mathrm{CBR}$, namun yang digunakan sebagai nilai CBR adalah nilai tertinggi dari keduanya.

Hasil perhitungan nilai CBR dapat dilihat selengkapnya pada Tabel 3. Nilai CBR tanah stabilisasi dengan 9\% abu vulkanik terlihat lebih tinggi sekitar 1,8 kali nilai CBR tanah pasir. Pasir yang digunakan dalam penelitian ini sulit untuk dipadatkan secara maksimal, hal ini berakibat pada hasil uji CBR yang memperlihatkan nilai yang cukup rendah, bahkan masih digolongkan sebagai tanah jelek karena memiliki nilai CBR lebih kecil 3\% (Bowles, 1992; Soedarsono, 1985).

Nilai CBR tanah stabilisasi $9 \%$ abu vulkanik terlihat efektif pada tebal di atas $16 \mathrm{~cm}$, nilai CBR yang didapat dapat mengubah karakteristik tanah lempung lunak yang jelek menjadi tanah lempung jelek ke sedang atau CBR rendah ke sedang (B

owles, 1992; Soedarsono, 1985). Seharusnya nilai CBR tanah stabilisasi masih dapat meningkat apabila tebal lapisannya diperbesar, akan tetapi penelitian masih diuji dalam skala kecil dengan menggunakan bak uji yang terbatas di laboratorium. Hasil lebih bisa didapatkan apabila dilakukan dengan model skala yang lebih besar atau skala penuh di lapangan. 


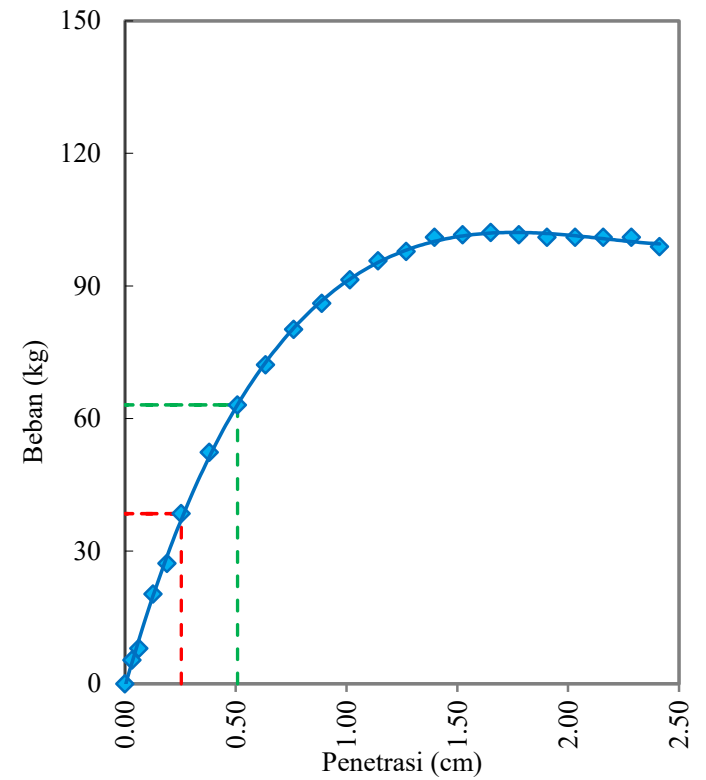

(a)

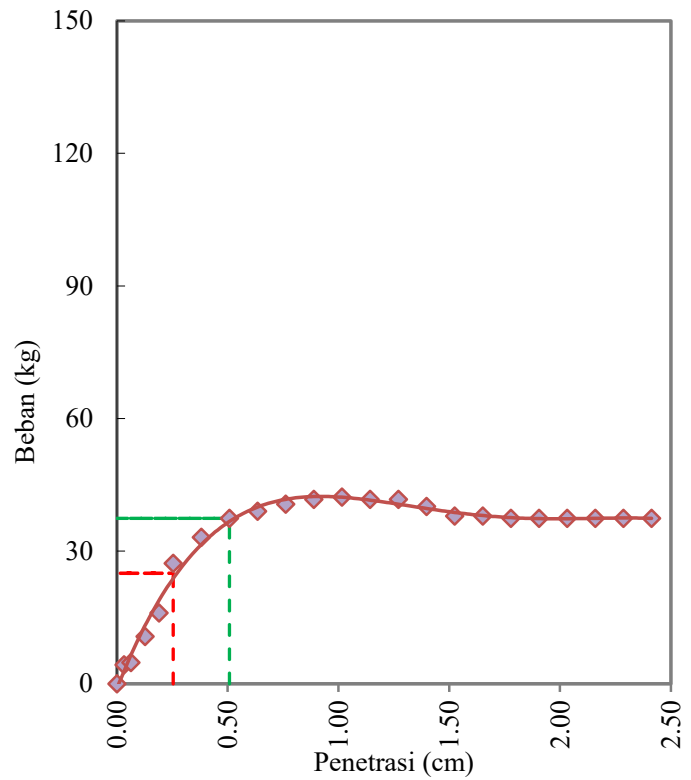

(b)

Gambar 9. Penentuan nilai CBR pada: (a) Tanah stabilisasi abu vulkanik; (b) Tanah dengan lapisan pasir $16 \mathrm{~cm}$

Tabel 3. Nilai CBR tanah berdasarkan ketebalan stabilisasi

\begin{tabular}{lll}
\hline $\begin{array}{l}\text { Tebal tanah } \\
\text { stabilisasi }\end{array}$ & $\begin{array}{l}\text { Nilai CBR (\%) } \\
\text { Abu vulkanik }\end{array}$ & $\begin{array}{l}\text { Nilai CBR (\%) } \\
\text { Pasir }\end{array}$ \\
\hline 0 & 0,09 & 0,09 \\
\hline 4 & 0,64 & 0,46 \\
\hline 8 & 1,50 & 0,79 \\
\hline 12 & 2,53 & 1,41 \\
\hline 16 & 3,09 & 1,84 \\
\hline 20 & 4,95 & 2,44 \\
\hline
\end{tabular}

\subsection{Pengaruh Tebal Tanah Terhadap Nilai CBR Tanah}

Pengaruh tebal tanah terhadap nilai CBR ditunjukkan dalam Gambar 10. Tebal lapisan tanah stabilisasi berpengaruh pada peningkatan nilai CBR tanah. Perbaikan tanah yang lebih tebal dapat meningkatkan nilai CBR, baik untuk tanah stabilisasi abu vulkanik maupun tanah pasir. Nilai CBR untuk tebal $16 \mathrm{~cm}$ dan $20 \mathrm{~cm}$ tanah stabilisasi dapat meningkat antara 34-55 kali nilai CBR tanah lunak. Peningkatan nilai CBR di atas ketebalan tanah stabilisasi $20 \mathrm{~cm}$ perlu diteliti pada penelitian berikutnya. Hasil penelitian ini menunjukkan masih ada kecenderungan peningkatan nilai CBR pada lapisan stabilisasi dengan tebal di atas $20 \mathrm{~cm}$. Menurut Hardiyatmo (2015), ketebalan tanah dasar sebagai pondasi jalan di lapangan adalah sekitar $60-90 \mathrm{~cm}$. Tanah stabilisasi yang tebal semakin kaku dan stabil dalam menahan beban, penurunan lapisan tanah lunak di bawahnya semakin kecil akibat bidang kontak beban semakin luas. Tanah stabilisasi abu vulkanik yang dipadatkan dengan kadar air optimum mengakibatkan perubahan volume tanah lunak sehingga terjadi perubahan kekuatan dan kekakuan pada tanah, hal ini sesuai dengan pernyataan (Hardiyatmo, 2015). Perbaikan tanah dengan 9\% abu vulkanik cukup mampu mengubah karakteristik tanah lempung lunak menjadi tanah sedang dengan kriteria CBR 
tanah dasar sedang. Hal berbeda didapatkan untuk tanah pasir, peningkatan CBR untuk tebal lapisan 16-20 cm hanya meningkat antara 20-27 kali nilai CBR tanah lunak.

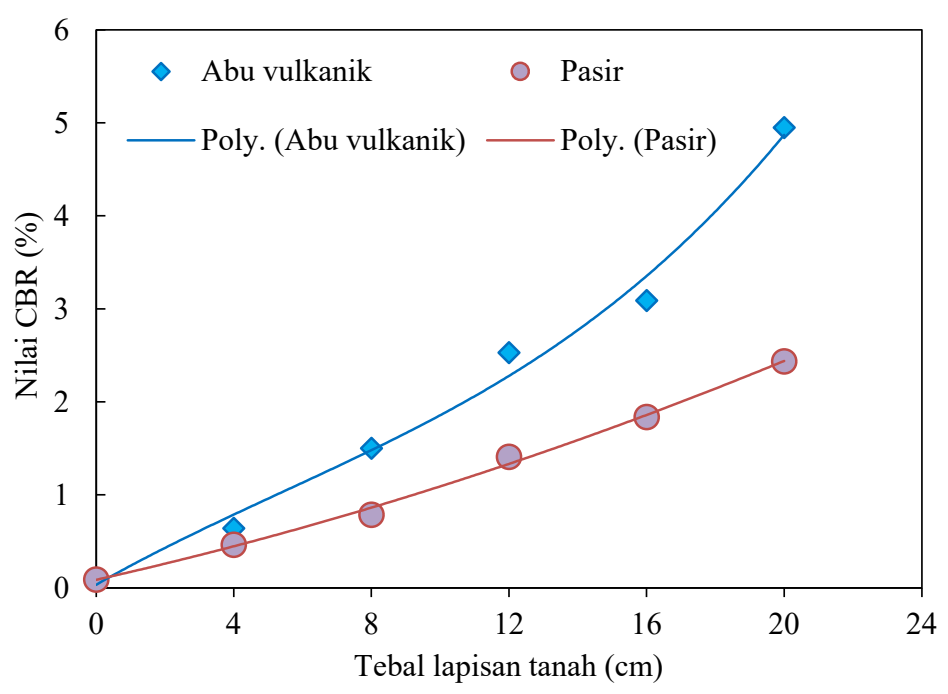

Gambar 10. Hubungan nilai CBR dengan tebal lapisan tanah stabilisasi

Ketebalan tanah stabilisasi berhubungan pada peningkatan nilai CBR tanah dasar dan nilai CBR tanah dasar digunakan sebagai dapar dalam perencanaan perkerasan jalan. Nilai CBR tanah dasar berperan penting dalam perencanaan tebal lapis perkerasan jalan (Akbar, 2013). Perkerasan dengan tanah dasar yang distabilisasi membutuhkan ketebalan lapisan aspal beton yang lebih sedikit dibandingkan dengan perkerasan dengan tanah dasar yang tidak distabilisasi, dengan demikian biaya perkerasan berkurang, pemeliharaan dan rehabilitasi perkerasan yang diperlukan berkurang, dan umur perkerasan meningkat (Rabab'ah et al., 2021).

Peningkatan nilai CBR pada tanah stabilisasi dipengaruhi oleh penambahan abu vulkanik. Perbaikan tanah lempung lunak dengan abu vulkanik melalui proses pemadatan dan pencampuran air. Abu vulkanik Sinabung mengandung 45,76\% Si (Silika), 14,27\% Al (Alumina), dan 10,55\% Ca (Calsium), sehingga dapat menjadi material pozzolan untuk stabilisasi tanah (Latif et al., 2016). Seperti diketahui bahwa abu vulkanik mengandung senyawa silika $(\mathrm{Si})$ yang tinggi, melalui proses kimiawi dan reaksi pertukaran ion pada partikel-partikel lempung dan proses penyerapan air melalui hidrasi menghasilkan partikel lempung yang menggumpal yang berakibat pada perbaikan konsistensi tanah. Reaksi abu vulkanik dengan material tanah lempung dan air akan membentuk senyawa yang mengeras, sehingga sifat-sifat tanah diperbaiki dan menjadi lebih kuat, kaku, dan tahan terhadap beban yang bekerja.

Tebal tanah stabilisasi memperlihatkan hubungan yang kuat terhadap perkalian nilai CBR dengan beban maksimum. Hubungan yang sama terlihat pada lapisan tanah pasir. Hal ini ditunjukkan pada Gambar 11. Hasil penelitian ini menegaskan bahwa tebal lapisan tanah yang distabilisasi perlu dipertimbangkan dalam perencanaan tanah dasar pada pembangunan konstruksi jalan. 


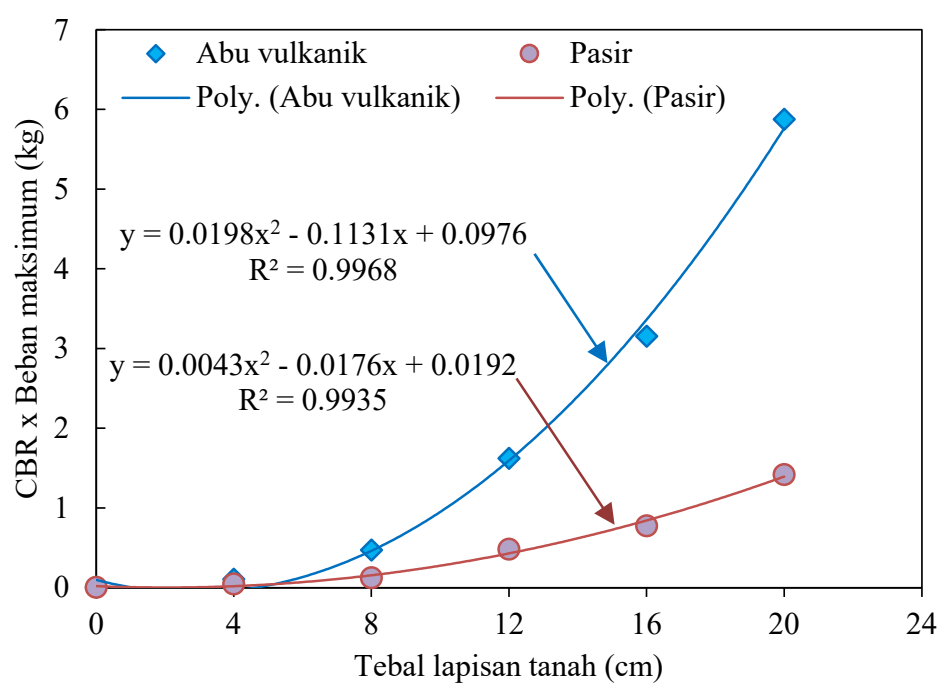

Gambar 11. Hubungan (CBR x beban maksimum) dengan tebal lapisan tanah stabilisasi

Faktor lain yang dapat dipertimbangkan dalam penelitian lanjutan adalah penambahan variabel tebal lapisan tanah stabilisasi dengan kajian pada beberapa jenis tanah. Jenis tanah dan bahan stabilisasi ikut memberikan andil dalam peningkatan CBR tanah. Sebagai bahan pertimbangan, dapat dilihat hubungan rasio beban maksimum terhadap tebal lapisan dengan nilai CBR yang dipaparkan pada Gambar 12.

Kedua jenis tanah memperlihatkan hubungan linier dengan CBR tanah. Walaupun hasil yang didapatkan kurang maksimal, namun cukup memberikan indikasi pada peningkatan nilai CBR. Hal ini disebabkan keterbatasan variasi tebal tanah dan jenis tanah yang diteliti. Oleh karena ini penelitian lanjutan dapat diarahkan pada kajian tebal yang lebih tinggi, jenis tanah, dan bahan stabilisasi yang variatif.

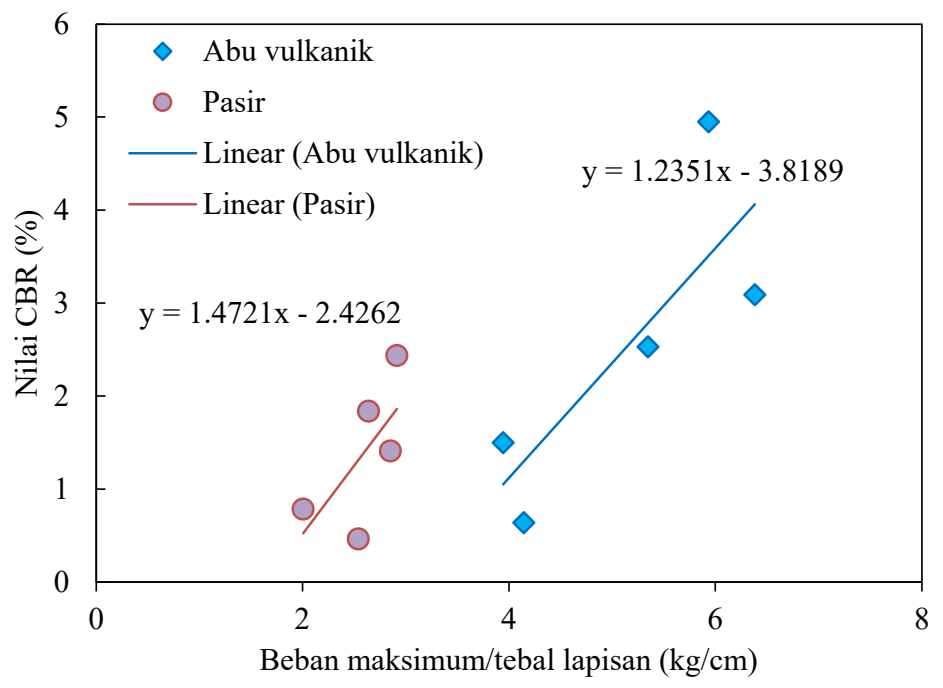

Gambar 12. Hubungan (beban maksimum/tebal lapisan) dengan CBR 


\section{KESIMPULAN}

Berdasarkan hasil uji kuat tekan bebas didapatkan bahwa penambahan $9 \%$ abu vulkanik pada tanah lunak dapat menghasilkan nilai kuat tekan tertinggi dan mengubah perilaku tanah lempung lunak menjadi sangat kaku. Tanah stabilisasi abu vulkanik lebih baik dibandingkan pasir, hal ini terlihat dari nilai CBR lebih tinggi 1,8 kali dari nilai CBR lapisan pasir. Tanah yang distabilisasi dapat dipadatkan secara maksimal, sedangkan pasir sulit dipadatkan.

Tebal tanah stabilisasi minimum yang menunjukkan peningkatan CBR yang signifikan didapatkan pada tebal di atas $16 \mathrm{~cm}$. Karakteristik tanah lunak berubah dari tanah jelek menjadi tanah sedang dengan nilai CBR sekitar 3-5\% pada tebal lapisan $16-20 \mathrm{~cm}$. Abu vulkanik yang digunakan untuk perbaikan tanah didapatkan cukup efektif dalam meningkatkan nilai CBR tanah, karena nilai CBR tanah stabilisasi dapat meningkat antara 34-55 kali nilai CBR tanah lunak. Tebal lapisan tanah stabilisasi berpengaruh pada peningkatan nilai CBR dan beban maksimum yang dapat dipikul tanah dasar. Apabila lapisan tanah stabilisasi cukup tebal, maka bidang kontak tekanan dari beban akan semakin luas sehingga daya dukung tanah semakin meningkat ditandai dari peningkatan nilai CBR dan beban maksimum sebelum runtuh.

\section{UCAPAN TERIMAKASIH}

Penulis berterimakasih kepada pihak-pihak yang terlibat dalam penelitian ini baik secara langsung maupun tidak langsung. Penulis juga mengucapkan terima kasih atas bantuan kepala Laboratorium Mekanika Tanah Institut Teknologi Medan dan juga kepada asisten laboratorium yang memberikan dukungannya hingga penelitian ini dapat terwujud.

\section{DAFTAR PUSTAKA}

Akbar, S. J. (2013). Kajian Pengaruh Nilai CBR Subgrade Terhadap Tebal Perkerasan Jalan. Teras Jurnal, 3(2), 138-147.

Alawiah, W. A., \& Yakin, Y. A. (2016). Analisis Daya Dukung Tiang Tunggal Statik pada Tanah Lunak di Gedebage. Jurnal Online Institut Teknologi Nasional, 2(3), 135-146.

Bowles, J. E. (1992). Engineering Properties of Soil and Their Measurement. McGraw-Hill Book Company Limited.

Darmawandi, A., Waruwu, A., Halawa, T., Harianto, D., \& Muammar. (2020). Karakterisitik Tanah Lunak Sumatera Utara Berdasarkan Pengujian Kuat Tekan Bebas. Semnastek UISU, 1, 16-20.

Darwis. (2017). Dasar-Dasar Teknik Perbaikan Tanah. Pustaka AQ.

Hardiyatmo, H. C. (2002). Mekanika Tanah I. Gajah Mada University Press.

Hardiyatmo, H. C. (2015). Pemeliharaan Jalan Raya. Gadjah Mada University Press.

Hardiyatmo, H. C. (2016). Alternatif Solusi Pembangunan Perkerasan Jalan Pada Subgrade Berdaya Dukung Rendah. Infoteknik, 2(7), 1-12.

Latif, D. O., Rifai, A., \& Suryolelono, K. B. (2016). Chemical characteristics of volcanic ash in indonesia for soil stabilization: Morphology and mineral content. International Journal of GEOMATE, 11(4), 2606-2610. https://doi.org/10.21660/2016.26.151120

Latif, D. O., Rifa'i, A., \& Suryolelono, K. B. (2017). Perbaikan Sifat Mekanis Tanah Lempung Ekspansif Menggunakan Abu Vulkanis Sinabung dan Kapur. Jurnal Saintis, 17(1), 24-32.

Moayed, R. Z., Allahyari, F., \& Nazari, M. (2012). Effect of The Sand Layer Thickness on The CBR Values of Two Layered Subgrade. 3rd International Conference on New Development in Soil Mechanics and Geotechnical Engineering Near East University, 437-444.

Rabab'ah, S., Al Hattamleh, O., Aldeeky, H., \& Abu Alfoul, B. (2021). Effect of Glass Fiber on The Properties of Expansive Soil and Its Utilization as Subgrade Reinforcement in Pavement Applications. Case Studies in Construction Materials, 14, 1-12. https://doi.org/10.1016/j.cscm.2020.e00485

Rinaldi, M. I., Gusrizal, \& Mulizar. (2020). Stabilisasi Tanah Lempung Menggunakan Abu Vulkanik Dan Abu Sekam Padi Ditinjau Dari Nilai California Bearing Ratio. Jurnal Sipil Sains Terapan, $3(2), 14-19$. 
Satria, Z., Fatnanta, F., \& Nugroho, S. A. (2020). Pengaruh Waktu Terhadap Daya Dukung Fondasi Tiang pada Tanah Lunak dengan Variasi Kekasaran. Jurnal Rekayasa Sipil, 16(1), 12-24.

Soedarsono. (1985). Konstruksi Jalan Raya. Badan Penerbit Pekerjaan Umum.

Sukirman, S. (1999). Dasar-dasar Perencanaan Geometrik Jalan. Nova.

Tornando, H., Fatnanta, F., \& Wibisono, G. (2020). Karakteristik Kuat Tekan Bebas Stabilisasi Semen Dan Kapur Tanah CL-ML Terhadap Siklus Pembasahan Pengeringan. Jurnal Rekayasa Sipil (JRS-Unand), 16(2), 105-118. https://doi.org/10.25077/jrs.16.2.105-118.2020

Triputro, F. A., \& Rahayu, T. (2016). Analisa Pengaruh Abu Vulkanik Gunung Kelud Pada Stabilisasi Tanah Lempung. Jurnal Konstruksia, Ұ(2), 75-82.

Waruwu, A. (2012). Peningkatan Nilai CBR Akibat Pemeraman pada Tanah Lempung dengan Penambahan Cornice Adhesive. A. S. P Jurnal, 1(1), 1-7.

Waruwu, A. (2013). Korelasi Nilai Kuat Tekan dan CBR Tanah Lempung yang Distabilisasi dengan Abu Batu dan Semen. Jurnal Rancang Sipil, 2(1), 99-108.

Wesley, L. D. (2017). Mekanika Tanah. Penerbit Andi.

Zaro, K., Nugroho, S. A., \& Fatnanta, F. (2014). Pengaruh Kadar Lempung dengan Kadar Air di atas OMC Terhadap Nilai CBR dengan dan Tanpa Rendaman pada Tanah Lempung Organik. Jom FTeknik, 1(2), 1-5. 